\title{
Fish Assemblages in the Degraded Mangrove Ecosystems of the Coastal Zone, Benin, West Africa: Implications for Ecosystem Restoration and Resources Conservation
}

\author{
Alphonse Adite $^{1 *}$, Ibrahim ImorouToko², Adam Gbankoto ${ }^{3}$ \\ ${ }^{1}$ PRECOB, Unité de Recherches sur les Zones Humides (URZH), Département de Zoologie, Faculté des Sciences et Techniques, \\ Université d'Abomey-Calavi, Cotonou, Bénin; ${ }^{2}$ Faculté d'Agronomie, Université de Parakou (UNIPAR), Parakou, Bénin; ${ }^{3}$ Dé- \\ partement de Physiologie Animale, Laboratoire de Pharmacologie, Faculté des Sciences et Techniques, Université d'Abomey-Calavi, \\ Cotonou, Bénin. \\ Email: ${ }^{*}$ alphonseadite@gmail.com
}

Received September $26^{\text {th }}, 2013$; revised October $27^{\text {th }}, 2013$; accepted November $26^{\text {th }}, 2013$

Copyright (C) 2013 Alphonse Adite et al. This is an open access article distributed under the Creative Commons Attribution License, which permits unrestricted use, distribution, and reproduction in any medium, provided the original work is properly cited. In accordance of the Creative Commons Attribution License all Copyrights (C) 2013 are reserved for SCIRP and the owner of the intellectual property Alphonse Adite et al. All Copyright (C) 2013 are guarded by law and by SCIRP as a guardian.

\begin{abstract}
Mangrove forests are unique habitats in their function as potential food source and nurseries, and support an important fisheries resource. In the Benin coastal zone, the mangrove fishes have been surveyed to investigate fish species diversity, community structures and ecosystem degradation impacts in order to protect and to improve the mangrove fish resources. Results from wet, high-water and dry season samplings revealed that the two dominant mangrove species, Rizophora racemosa and Avicennia africana, are being intensively degraded for domestic use such as firewood and house building. Fifty one (51) fish species belonging to 25 families were recorded with Eleotridae (7 species), Cichlidae (5 species), and Mugilidae (5 species), the most speciose families. Dominant trophic guilds were detritivores $(54.57 \%)$ and planktinovores/microcarnivores (30.41\%). Six (6) species, Sarotherodon melanotheron, Dormitator lebretonis, Gerres melanopterus, Hemichromis fasciatus, Ethmalosa fimbriata, and Aplocheilichthys spilauchen, dominated the samples and accounted for about $80.27 \%$. Sarotherodon melanotheron constituted the major dominant species and accounted numerically for about $29 \%$ of the total catches and $46.7 \%$ of the total biomass. The Margalef index of species richness ranged between 2.42 and 4.43, the Shannon-Weaver index of species diversity between 1.39 and 2.27, and the evenness between 0.50 and 0.62 . Lower indices were observed for the highly degraded and the moderately degraded sites whereas higher indices were recorded for the less degraded and the restored sites. Species richness, species diversity and dominant species abundance were positively correlated with depth and transparency and negatively correlated with temperature. Multi-species fisheries dominate the coastal zone with Sarotherodon melanotheron, Dormitator lebretonis, Gerres melanopterus, Ethmalosa fimbriata, Liza falcipinus, Mugil sp. and Chrysichthys nigrodigitatus, the major species in the commercial catches. In addition to the mangrove destruction, the hydro electrical dam have greatly modified the Mono River flooding regime, water quality and the fish composition of the Benin coastal lagoon system. An integrated approach of the mangrove resource management/conservation, including intensive mangrove restoration, management of key fish species, freshwater prawns (Macrobrachiun sp.), peneids shrimps, mangrove oysters (Crassostrea sp.), and crabs (Callinectes sp., Cardiosoma sp.), and habitat protection is required for ecosystem recovery and sustainable exploitation.
\end{abstract}

Keywords: Conservation; Detritivores; Diversity; Evolutionary Process; Fragmentized Habitats; Hydroelectrical Dam; Mangrove Degradation; Multi-Species Fisheries

\section{Introduction}

Mangrove forests are prevalent in many West African

"Corresponding author. coastal zones where they play determinant ecological role in the ecotonal communities [1-3]. Mangrove provides shelters for most fish inhabiting the coastal zones $[4,5]$ and serves as nursery grounds for many species, 
such as shrimps and most commercial fish species [6-8]. Fisheries success in many tropical coastal zones depends on mangrove health because they serve as spawning and nursery grounds for most species. However, mangroves are still being destroyed in many wetlands. In Benin, the coastal lagoons remain the only sites where mangroves are still well-structured. But these mangroves are being intensively destroyed for firewood, housing, salt processing and to build the "Akadja" (park of branches installed in the lagoons and utilized to attract fishes) [9-11]. Other major sources of degradation at the coastal lagoons, are the hydro electrical dam constructed on the Mono River and the invasion of the water hyacinth, Eichhornia crassipes [5]. Moreover, fishes, shrimps and shellfishes resources of the coastal lagoons are overexploited because of the increasing fishermen population and the use of detrimental fishing gears.

These multiple uses and degradations factors of the coastal lagoons are profoundly affecting the density and health of the mangrove habitat, the physical environment and the structure of the fish community. However, knowledge on mangrove fish is not well documented and is limited to some poor information on commercial fishes such as cichlids, mullets and clupeids [10]. Especially, little is known about the mangroves fish community structure such as species abundance, richness, diversity and distribution in the degrading mangrove zone. These community structure indices are badly needed to design an appropriate framework of the mangrove fish conservation and the overall ecosystem restoration plan.

The present study was undertaken in the Benin coastal lagoons to obtain information related to physical environment, mangrove fish species distribution, population structure and degradation in order to improve mangrove fish resource management and conservation in West Africa. Specific objectives were 1) to investigate fish assemblages, distribution and structure of the fish community in the mangrove habitat; 2) to investigate relationships between environment features and fish community indices; 3) to evaluate mangrove degradation and status according to site, and impacts on fish population; 4) to survey socioeconomic aspects of resources exploitation and 5) to design an ecosystem restoration and resource conservation plan in participatory approaches with grassroots.

\section{Methods}

\subsection{Study Region}

The study region is the mangrove ecosystem of the Benin coastal zone (Figure 1). This region covers about 3000 ha of mangrove and extended on about $130 \mathrm{~km}$. The climate is sub equatorial with two (2) wet seasons (April to July; mid-September to October) and two (2) dry seasons (December to March; mid-August to mid-September). Annual mean rainfall is about $1307.3 \mathrm{~mm} \mathrm{[12]} \mathrm{and} \mathrm{am-}$ bient temperature varies between $25^{\circ} \mathrm{C}$ and $27.7^{\circ} \mathrm{C}$. Swamps cover about 6000 ha and flooding at the coastal zones depends on the Mono River on which a dam is constructed for electrical power. This hydro electrical dam greatly affects the flooding regime of the coastal zone and the biological resources. Though very diverse, the plant communitiy at the coastal zone is dominated by Rizophora racemosa and at some extent Avicennia africana. Rizophora racemosa grows in the intertidal zone while Avicennia africana grows on the adjacent wetland at the back part of Rizophora racemosa. At some sites, a

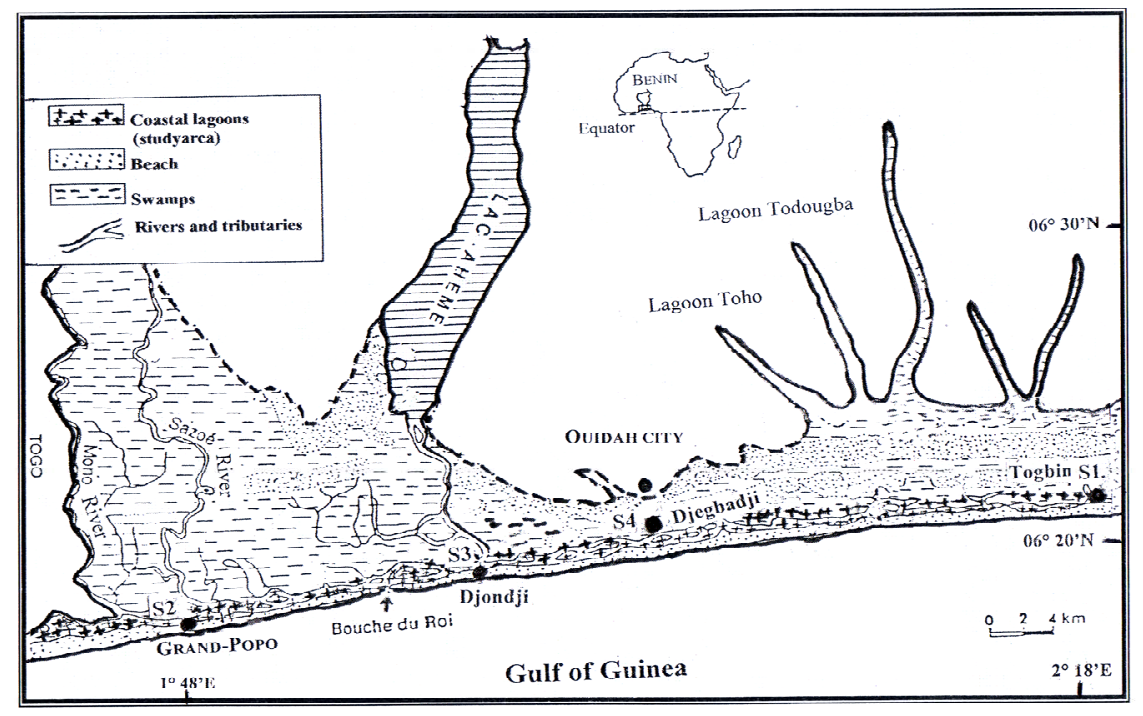

Figure 1. Map showing the sampling sites at the Benin coastal Lagoons: $\mathrm{S} 1=$ Togbin, $\mathrm{S} 2=\mathrm{Grand}-\mathrm{Popo}, \mathrm{S} 3=\mathrm{Djondji}, \mathrm{S} 4=$ Djegbadji. 
seagrass, Cyperus articulatus is well established in the water. Beside its nursery role, Cyperus articulatus is exploited by women for mat processing. The habitats where mangroves were destroyed are mostly colonized by a grass, Paspalum vaginatum. Along the coastal zone, there was a vast plantation of Coco nucifera which is exploited for oil and food. Also, a palm-tree species, Elaeis guineensis is common in the adjacent plant community of the coastal zone. All these species are associated with other plant species such as Drepanocarpus lunatus, Dalbergia ecastaphyllum, Laguncularia racemoa, Thespesia populnea, Annona senegalensis, Bridelia ferruginea, Imperata cylindrica, Sesuvium postulacastrum, Phyloxesus vermicularias, Acrostichum aureum.

\subsection{Sampling Sites}

Four sites were selected at the Benin coastal zone for the sampling (Figure 1; Table 1). Sites were classified according to the degree of mangrove degradation. Site 1 ("Highly degraded site"), located at Togbin village, was characterized by a daily cutting of mangrove for firewood. From this village, a huge volume of mangrove wood were transported to other villages and towns; Site 2 ("Moderately degraded site") is located at Grand-Popo town where mangrove forest is moderately degraded; Site 3 ("Less degraded site") is located at Djondji village where the destruction of mangrove forest is prohibited by traditional law; Site 4 ("Restored site") is located at Djegbadji village where the mangrove forest have been once severely degraded, but have been restored through reforestation. At each site, samplings were made in four ecological habitats namely 1) mangroves fringe, 2) adjacent marginal vegetation (grass), 3) channel and 4) adjacent open water. At each sampling site, when available, an attempt was made to sample these four habitats.

\subsection{Habitat Evaluation}

Each sampling site was evaluated. Evaluation were made on habitat type, water type, dominant terrestrial habitat, utilization of adjacent land and wetland, aquatic vegeta- tion, dominant mangrove species, mangrove cutting/degradation, substrate, pollution, atmospheric conditions and water physico-chemical conditions. Water samples were collected by a hydrobios sampler. Water depth was measured to the nearest millimeter using a graduated rope, turbidity was measured to the nearest millimeter with a secchi disk, temperature and dissolved oxygen were measured to the nearest $0.1^{\circ} \mathrm{C}$ and $0.1 \mathrm{mg} \cdot l^{-1}$ respectively with a digital oxythermometer, $\mathrm{pH}$ was measured to the nearest 0.1 with a model 3150 waterproof $\mathrm{pH}$ meter and salinity was measured to the nearest $1 \%$ with a model VISTA refractometer. Habitat evaluation and fish collection were made twice during dry, wet and transitional season (flooding period).

\subsection{Fish Collection}

Fishes were captured at all sampling sites using appropriate set of fishing gears so that common fish species would be well represented and samples reflect the relative abundance of fish population. Also, the use of various collecting gears helped to increase the likelihood of rare species to occur in the fish sample. At the four habitats, fishes were sampled from March 2010 to February 2011 with seines $(6.15 \mathrm{~m} \times 2 \mathrm{~m}, 16 \mathrm{~mm}$ mesh; $2 \mathrm{~m} \times 1.8$ $\mathrm{m}, 5 \mathrm{~mm} \mathrm{mesh})$, cast nets (6 $\mathrm{m}$ diameter, $20 \mathrm{~mm}$ mesh), experimental gill net $(200 \mathrm{~m} \times 1.30 \mathrm{~m}, 50 \mathrm{~mm}$ mesh; 200 $\times 1.30 \mathrm{~m}, 40 \mathrm{~mm}$ mesh; $200 \mathrm{~m} \times 1.30 \mathrm{~m}, 25 \mathrm{~mm}$ mesh). Samplings in marginal aquatic vegetation and channel were made with small seine by setting the seine stationary, and kicking the vegetation to drive the fish in to the net before lifting it. At the mangrove fringe, seine hauls were made close to the intertidal roots system. Cast nets were used very close to the mangrove with the help of fishermen. The net, once casted cover a defined area and is maintained stationary. All trapped fishes were then removed by hands from the mud before the cast net was pulling out. This method increases the efficiency of the cast net. Gill nets were set very close to the mangrove, yet, contribute very little to the total sample. A crosslake fish trap built by the fishermen was used for sampling. This gear possesses some final catching chamber and is set in open water in a sand mud or muddy envi-

Table 1. Geographic coordinates of the sampling sites.

\begin{tabular}{|c|c|c|c|c|}
\hline \multicolumn{5}{|c|}{ Geographic coordinates } \\
\hline Sampling sites & Site name & Mangrove status & Longitude & Latitude \\
\hline Site 2 & Grand-Popo town & Moderately degraded & $06^{\circ} 17^{\prime} 11.4^{\prime \prime} \mathrm{N}$ & $001^{\circ} 48^{\prime} 39.7 " \mathrm{E}$ \\
\hline Site 3 & Djondji village & Less degraded & $06^{\circ} 18^{\prime} 13.8^{\prime \prime} \mathrm{N}$ & $001^{\circ} 58^{\prime} 15.3^{\prime \prime} \mathrm{E}$ \\
\hline Site 4 & Djegbadji village & Restored & $06^{\circ} 19^{\prime} 55.5^{\prime \prime} \mathrm{N}$ & $002^{\circ} 05^{\prime} 12.0 " \mathrm{E}$ \\
\hline
\end{tabular}


ronment. The use of various fishing gears at the mangrove sites helped to assess the whole mangrove fish species. Once caught, the fish samples were identified, measured, weighted and preserved in $10 \%$ formalin and latter in $70 \%$ ethanol for further laboratory observation. Species identification was based on references such as Lopez-Fernandez et al. (2003) [13], Leveque et al. (1990a, 1990b) [14,15], Holden and Reed (1972) [16], and Lowe McConnell $(1975,1987)[17,18]$.

\subsection{Survey on Mangrove Utilization and Degradation}

Artisanal fishermen were potential users and beneficiaries of the mangrove resource and know a lot about this ecosystem. A survey was implemented in fishing villages to investigate on degradation and mangrove resources utilization. A survey guide was used for this investigation.

\subsection{Data Analysis}

Species abundance and relative abundance were computed to indicate the numerical importance of each species in the sample. Species richness $(d)$ was determined following Margalef, (1968) index [19]:

$$
d=S-1 / \operatorname{Ln} N
$$

where $S$ is the number of species and $N$ the number of individuals in the sample. Species diversity $\left(H^{\prime}\right)$ was determined following Shannon and Weaver (1963) index of diversity $[20,21]$ :

$$
H^{\prime}=-\sum(p i) * \log 10(p i)
$$

where $H^{\prime}$ is the index of species diversity, $p i=n i / N$, the proportion of total sample belonging to $i$ th species, $n i$ the number of individuals of each species in the sample, $N$ the total number of individuals of all species in the sample. The evenness measure of Shannon-Weaver $\left(J^{\prime}\right)$ function was computed following the formula:

$$
J^{\prime}=H^{\prime} / \log S
$$

where $H^{\prime}$ is the Shannon and Weaver index of diversity, $\mathrm{S}$ is the number of species in the sample. For this study, these three indexes (richness, diversity, evenness) were computed for each habitat. I used the PC-ORD [22] computer program to generate species diversity indexes, species richness and evenness. The PC-ORD software is a multivariate analysis tool for ecological data.

To explore the trophic structure of the fish community, I categorized fishes in five trophic categories which were 1) detritivores, 2) planktinovores/microcarnivores, 3) herbivores, 4) intermediate carnivores and 5) top-carnivores [23-25]. Previous studies from Halliday \& Young [25], Adite \& Winemiller [26], Adite et al., [27] on diet were used for this classification. The importance of each trophic category was appreciated using the relative abundance of fish species. The relationships between the fish community attributes and physico-chemical attributes were evaluated through linear regression analysis and F-test using SPSS software package [28].

For dominant species (Dormitator lebretonis, Aplocheilichthys spilauchen, Ethmalosa fimbriata, Gerres melanopterus, Hemichromis fasciatus, Sarotherodon melanotheron), frequency histograms of fish size intervals were constructed for samples according to habitat type using Excel software. With SPSS software [28], length-weight relationships were examined for different species by habitats type according to the model:

$$
W=a T L^{b}
$$

and its log-linear form

$$
\log W=\log a+b \log T L
$$

where $T L$ is the total length, $W$ is the individual weight, $a$ is a constant, and $b$ is the allometry coefficient [29]. Univariate analysis of variance was used to test the significance of the regression equations using SPSS software package [28].

\section{Results}

\subsection{Hydrology and Habitat Characteristics}

The Benin mangrove ecosystem is a brackish water receiving freshwater from the Mono River (South-Benin) and salty water from Atlantic Ocean. Significant variations $(\mathrm{P}<0.05)$ of the water quality features were recorded among the different sites sampled. Depths varied from 5 to $447 \mathrm{~cm}$ (mean: $81.93 \mathrm{~cm}$ ), transparencies from 3 and $150 \mathrm{~cm}$ (mean: $41 \mathrm{~cm}$ ). Water temperatures ranged between $25.3^{\circ} \mathrm{C}$ and $35.2^{\circ} \mathrm{C}$ (mean: $30.8^{\circ} \mathrm{C}$ ), $\mathrm{pH}$ between 5.5 and 8.7 (mean: 6.7), dissolved oxygen between 0.1 and $8.5 \mathrm{mg} / 1$ (mean: 5.7), and salinities between $0 \%$ and 35\% (mean: 20.1\%o) (Table 2). Particularly, transitional season (flood) salinities were relatively low and vary between $0 \%$ and $20 \%$ (mean: $14.4 \%$ ) because of the flooding from the Mono River during this period. Wet and dry season salinities were relatively high and ranged from $0 \%$ to $35 \%$ (mean: $23 \%$ ) and $10 \%$ to $35 \%$ (mean: $24 \%$ ), respectively. Salinities from sites close to the tidal pass were always high and oceanic (Djondji village: $31 \%$ - 33\%o). Also, the water quality was predominantly freshwater at sites close to the Mono River mouth where salinities were always low (Grand-Popo village: $0 \% 0$ - 6\%).

\subsection{Ichtyofaunal Composition, Abundance and Diversity Indices}

Overall, 7894 individual fishes comprising 51 species 
Table 2. Ranges and mean values of the water parameters measured in four habitat categories of the Benin mangrove ecosystem at the coastal zone.

\begin{tabular}{cccccccccc}
\hline & \multicolumn{2}{c}{ Highly degraded site } & \multicolumn{2}{c}{ Moderatly degraded site } & \multicolumn{2}{c}{ Less degraded site } & \multicolumn{2}{c}{ Restored site } \\
\hline Water features & Mean & Range & Mean & Range & Mean & Range & Mean & Range \\
\hline Depth $(\mathrm{cm})$ & 20.7 & $5-50$ & 26.2 & $10-54$ & 125.3 & $98-405$ & 155.5 & $112-447$ \\
Transparency $(\mathrm{cm})$ & 18.5 & $3-50$ & 21.6 & $10-37$ & 46.5 & $14-100$ & 77.4 & $11-150$ \\
Temperature $\left({ }^{\circ} \mathrm{C}\right)$ & 32.3 & $27.5-35.2$ & 31.1 & $28.1-34.6$ & 30.0 & $26.6-34.5$ & 29.7 & $25.3-33.0$ \\
Ph & 5.5 & $5.5-7.1$ & 6.4 & $6.3-8.2$ & 7.5 & $7.0-8.0$ & 7.4 & $6.8-8.7$ \\
Dissolved oxygen $(\mathrm{mg} / \mathrm{l})$ & 5.8 & $0.1-7.5$ & 5.6 & $3.0-8.0$ & 5.4 & $3.5-8.5$ & 5.9 & $4.0-7.9$ \\
Salinity $(\%)$ & 34 & $32-35$ & 4.0 & $0-6.0$ & 32 & $31-33$ & 24.2 & $12-35$ \\
\hline
\end{tabular}

belonging to 33 genera and 25 families were collected from March 2010 to September 2011 (Table 3). The number of species recorded in the "highly degraded site", "moderately degraded site", "less degraded site" and in the "restored site" were 16, 19, 29 and 38, respectively. The most speciose families were Eleotridae ( 7 species), Cichlidae (5 species) and Mugilidae (5 species). The families Eleotridae, Cichlidae, Mugilidae, Cyprinotontidae, Gerreidae and Clupeidae numerically dominated the sample and accounted together for $93.21 \%$. Also, six species Dormitator lebretonis, Sarotherodon melanotheron, Gerres melanopterus, Ethmalosa fimbriata, Hemichromis fasciatus, and Aplocheilichthys spilauchen dominated the sample and accounted together for $80.27 \%$. Sarotherodon melanotheron, alone, constituted 28.98\% of the total sample followed by Dormitator lebretonis (15.19\%), Aplocheilichthys spilauchen (13.71\%), Gerres melanopterus (12.90\%), Ethmalosa fimbriata (4.84\%) and Hemichromis fasciatus (4.65\%). The remaining $(19.73 \%)$ was shared by 45 species and none of them had individually a relative abundance more than $2.65 \%$. Fish relative numeric abundances in highly degraded and moderately degraded sites were lower and accounted for 6.17\% (biomass: $2.12 \%$ ) and $9.12 \%$ (biomass: $5.89 \%$ ), respectively. In term of biomass, the 7894 fishes collected weighted 95106.7 g. Seven species S. melanotheron, D. lebretonis, G. melanopterus, E. fimbriata, $H$. fasciatus, L. falcipinnis and $C$. nigrodigitatus constituted for about $84.41 \%$ of the total biomass. $S$. melanotheron, alone, constituted $46.66 \%$ of the total biomass. The remaining $(15.59 \%)$ is shared by 45 species and none of them had individually a biomass more than $3.62 \%$.

Aggregated site samples used to generate community indices indicated that the Margalef index (D) [19] of species richness ranged between 2.42 and 4.43, the Shannon-Weaver index of species diversity between 1.39 and 2.27, and the evenness between 0.50 and 0.62 (Table 4). In general, lower indices were observed for the highly degraded and the moderately degraded sites whereas higher indices were recorded for the less degraded and the restored sites.

\subsection{Trophic Structure of Fish Composition}

The mangrove fish community was numerically dominated by detritivores $(54.57 \%)$ and planktinovores/microcarnivores $(30.41 \%)$. Though not numerically important, the intermediate carnivores $(4.7 \%)$ and the top-carnivores $(6.6 \%)$ comprised an important number of species, 15 and 15, respectively (Table 5), and had a relatively low biomass percentage of $5.6 \%$ and $10.5 \%$, respectively. Herbivores species (Tilapia guinensis, Tilapia zillii) comprised $3.66 \%$. In terms of biomass, detritivores dominated the sample $(68.2 \%$ of the total biomass $)$ due to the predominance of $S$. melanotheron, reaching $46.7 \%$ of the total biomass.

\subsection{Size Structures}

Overall, the fish size (total length) in the mangrove zone ranged from $7 \mathrm{~mm}$ (G. melanopterus) to $440 \mathrm{~mm}$ (Clarias gariepinus) and their corresponding weights were $0.1 \mathrm{~g}$ and $525 \mathrm{~g}$, respectively. Larger fish were found in the less degraded site and in the restored site (Figures 2-8) whereas smaller fish (A. spilauchen, D. lebretonis, Epyplatys sp., Pellonula sp.) were found in "highly degraded site" and in the "moderately degraded site". Larger sizes were found among Cichlidae, Mugilidae, Clariidae, Elopidae, Belonidae, Bagridae and Cynoglossidae.

\subsection{Environmental Correlates}

Species richness and dominant species abundance were plotted against water parameters (temperature, $\mathrm{pH}$, dissolved oxygen, transparency, salinity, depth) to explore the relationships between fishes and abiotic factors. Though not significant, species richness was positively correlated with dissolved oxygen $\left(r^{2}=0.12\right)$. The cichlid 
Table 3. Fish species composition, abundance, size range and mean, weight range and mean, and total weight of the mangrove fishes in the Benin coastal zone. Data are combined samples from cast net, seine, gill net and cross-lake fish trap.

\begin{tabular}{|c|c|c|c|c|c|c|}
\hline Species families & Total Num. & SL range (mm) & SL mean (mm) & Weight range (g) & Weight mean (g) & Total weight (g) \\
\hline \multicolumn{7}{|l|}{ Belonidae } \\
\hline Strongylura senegalensis & 6 & $242-275$ & 257.3 & $25-33$ & 28.5 & 171 \\
\hline \multicolumn{7}{|l|}{ Bothidae } \\
\hline Citharichthys stampflii & 86 & $30-130$ & 79.7 & $0.5-50$ & 10.8 & 933 \\
\hline \multicolumn{7}{|l|}{ Carangidae } \\
\hline Caranx hippos & 88 & $50-82$ & 64.6 & $2-50$ & 7.6 & 671 \\
\hline \multicolumn{7}{|l|}{ Cichlidae } \\
\hline Sarotherodon melanotheron & 2288 & $8-189$ & 72.1 & $0.1-220$ & 19.3 & 44,375 \\
\hline Tilapia zillii & 109 & $47-175$ & 83.1 & $4-250$ & 31.5 & 3440 \\
\hline Tilapia guineensis & 180 & $13-220$ & 56.6 & $0.25-455$ & 12.1 & 2182 \\
\hline Hemichromis fasciatus & 367 & $15-158$ & 74.1 & $0.1-150$ & 16.5 & 6088 \\
\hline Hemichromis bimaculatus & 102 & $21-67$ & 36.3 & $0.3-15$ & 2.5 & 253 \\
\hline \multicolumn{7}{|l|}{ Clariidae } \\
\hline Clarias gariepinus & 5 & $215-440$ & 279 & $65-520$ & 203.6 & 1018 \\
\hline \multicolumn{7}{|l|}{ Claroteidae } \\
\hline Chrysichthys nigrodigitatus & 107 & $62-275$ & 118.7 & $4-420$ & 41.5 & 4446 \\
\hline \multicolumn{7}{|l|}{ Clupeidae } \\
\hline Ethmalosa fimbriata & 382 & $49-130$ & 76.8 & $2-48$ & 10 & 3832 \\
\hline Pellonula sp. & 209 & $29-95$ & 71 & $0.15-10$ & 5 & 1061 \\
\hline \multicolumn{7}{|l|}{ Cynoglossidae } \\
\hline Cynoglossus senegalensis & 2 & $313-315$ & 314 & $86-94$ & 90 & 180 \\
\hline \multicolumn{7}{|l|}{ Cyprinotontidae } \\
\hline Aplocheilichthys spilauchen & 1082 & $14-83$ & 31.4 & $0.1-5$ & 1 & 1068 \\
\hline Epiplatys sp. & 2 & $19-26$ & 22.5 & $0.1-0.1$ & 0.1 & 0.2 \\
\hline \multicolumn{7}{|l|}{ Eleotridae } \\
\hline Dormitator lebretonis & 1199 & $19-80$ & 51.8 & $0.2-13$ & 3.8 & 4650 \\
\hline Kriba nana & 39 & $21-65$ & 35 & $0.3-9$ & 1.4 & 56 \\
\hline Dormitator pleurops & 1 & $30-30$ & 30 & $0.8-0.8$ & 0.8 & 0.8 \\
\hline Eleotris daganensis & 2 & $93-93$ & 93 & $21-25$ & 23 & 46 \\
\hline Eleotris vitatta & 7 & $78-155$ & 97.8 & $9-100$ & 54.5 & 205 \\
\hline Eleotris senegalensis & 6 & $29-105$ & 48.6 & $0.3-34$ & 7 & 42 \\
\hline Eleotris $s p$. & 77 & $30-180$ & 85.8 & $0.5-190$ & 24.2 & 1867 \\
\hline \multicolumn{7}{|l|}{ Elopidae } \\
\hline Elops lacerta & 36 & $100-190$ & 136.7 & $10-90$ & 30.5 & 1101 \\
\hline Elops senegalensis & 5 & $131-176$ & 155.2 & $24-50$ & 37.2 & 186 \\
\hline
\end{tabular}


Fish Assemblages in the Degraded Mangrove Ecosystems of the Coastal Zone, Benin,

\begin{tabular}{|c|c|c|c|c|c|c|}
\hline Gerreidae & & & & & & \\
\hline Gerres melanopterus & 1018 & $7-118$ & 59.8 & $0.1-30$ & 6.2 & 6388 \\
\hline Gerres nigri & 2 & $74-89$ & 81.5 & $9-17$ & 13 & 26 \\
\hline \multicolumn{7}{|l|}{ Gobiidae } \\
\hline Oxyurichthys occidentalis & 87 & $43-130$ & 95.2 & $2-31$ & 12.5 & 1091 \\
\hline Progobius schlegeli & 25 & $40-99$ & 72.5 & $1-22$ & 9.1 & 228 \\
\hline \multicolumn{7}{|l|}{ Lutjanidae } \\
\hline Lutjanus goriensis & 11 & $30-118$ & 62.4 & $3-70$ & 14.7 & 162 \\
\hline Lutjanus agennes & 4 & $48-72$ & 57.7 & $4-13$ & 6.5 & 26 \\
\hline Lutjanus sp. & 4 & $60-114$ & 83.5 & $5-144$ & 20.3 & 81 \\
\hline \multicolumn{7}{|l|}{ Mochokidae } \\
\hline Synodontis sp. & 1 & $93-93$ & 93 & $14-14$ & 14 & 14 \\
\hline \multicolumn{7}{|l|}{ Monodactylidae } \\
\hline Psettia sebae & 9 & $27-55$ & 41.6 & $2-15$ & 9 & 81 \\
\hline \multicolumn{7}{|l|}{ Mugilidae } \\
\hline Liza falcipinnis & 179 & $23-195$ & 100.1 & $0.4-135$ & 27.8 & 4979 \\
\hline Mugil curema & 62 & $52-160$ & 101.8 & $3-92$ & 24.5 & 1521 \\
\hline Mugil bananensis & 2 & $102-255$ & 178.5 & $21-240$ & 130.5 & 261 \\
\hline Mugil cephalus & 1 & $163-163$ & 63 & $92-92$ & 92 & 92 \\
\hline Mugil sp. & 25 & $77-162$ & 102.7 & $9-76$ & 24.5 & 612.5 \\
\hline Liza sp. & 22 & $15-29$ & 22.4 & $0.2-0.4$ & 0.28 & 6.2 \\
\hline \multicolumn{7}{|l|}{ Ophichthyidae } \\
\hline Myrophis plumbeus & 1 & $395-395$ & 395 & $46-46$ & 46 & 46 \\
\hline Dalophis sp. & 1 & $475-475$ & 475 & $32-32$ & 32 & 32 \\
\hline \multicolumn{7}{|l|}{ Ophiocephalidae } \\
\hline Parachana obscura & 1 & $240-240$ & 240 & $220-220$ & 220 & 220 \\
\hline \multicolumn{7}{|l|}{ Polynemidae } \\
\hline Galeoides decadactylus & 2 & $50-78$ & 64 & $3-10$ & 6.5 & 13 \\
\hline \multicolumn{7}{|l|}{ Pomadasydae } \\
\hline Pomadasys jubelini & 4 & $84-145$ & 116 & $12-80$ & 50 & 200 \\
\hline Pomadasys peroteti & 1 & $92-92$ & 92 & $13-13$ & 13 & 13 \\
\hline Pomadasys sp. & 11 & $57-113$ & 83.4 & $6-40$ & 16.1 & 117 \\
\hline \multicolumn{7}{|l|}{ Protopteridae } \\
\hline Protopterus annectens & 1 & $340-340$ & 340 & $165-165$ & 165 & 165 \\
\hline \multicolumn{7}{|l|}{ Scombridae } \\
\hline Cybium sp. 1 & 14 & $88-120$ & 108.2 & $8-20$ & 14.8 & 208 \\
\hline Cybium sp. 2 & 12 & $60-98$ & 80 & $7-34$ & 19.9 & 239 \\
\hline
\end{tabular}


Continued

\begin{tabular}{|c|c|c|c|c|c|c|}
\hline Serranidae & & & & & & \\
\hline Epinephelus aeneus & 2 & $145-250$ & 197.5 & $68-340$ & 204 & 408 \\
\hline \multicolumn{7}{|l|}{ Syngnathidae } \\
\hline \multicolumn{7}{|l|}{ Microphis brachyurus } \\
\hline Aculeatus & 5 & $100-116$ & 108.2 & $0.5-3$ & 1 & 5 \\
\hline Total number of families & 25 & & & & & \\
\hline Total number of genera & 33 & & & & & \\
\hline Total number of species & 51 & & & & & \\
\hline Total number of individuals & 7894 & & & & & \\
\hline
\end{tabular}

Table 4. Fish relative abundances and diversity indices by habitat type in the mangrove ecosystem of the Benin coastal zone. Highly degraded site and moderately degraded site exhibited lower indices.

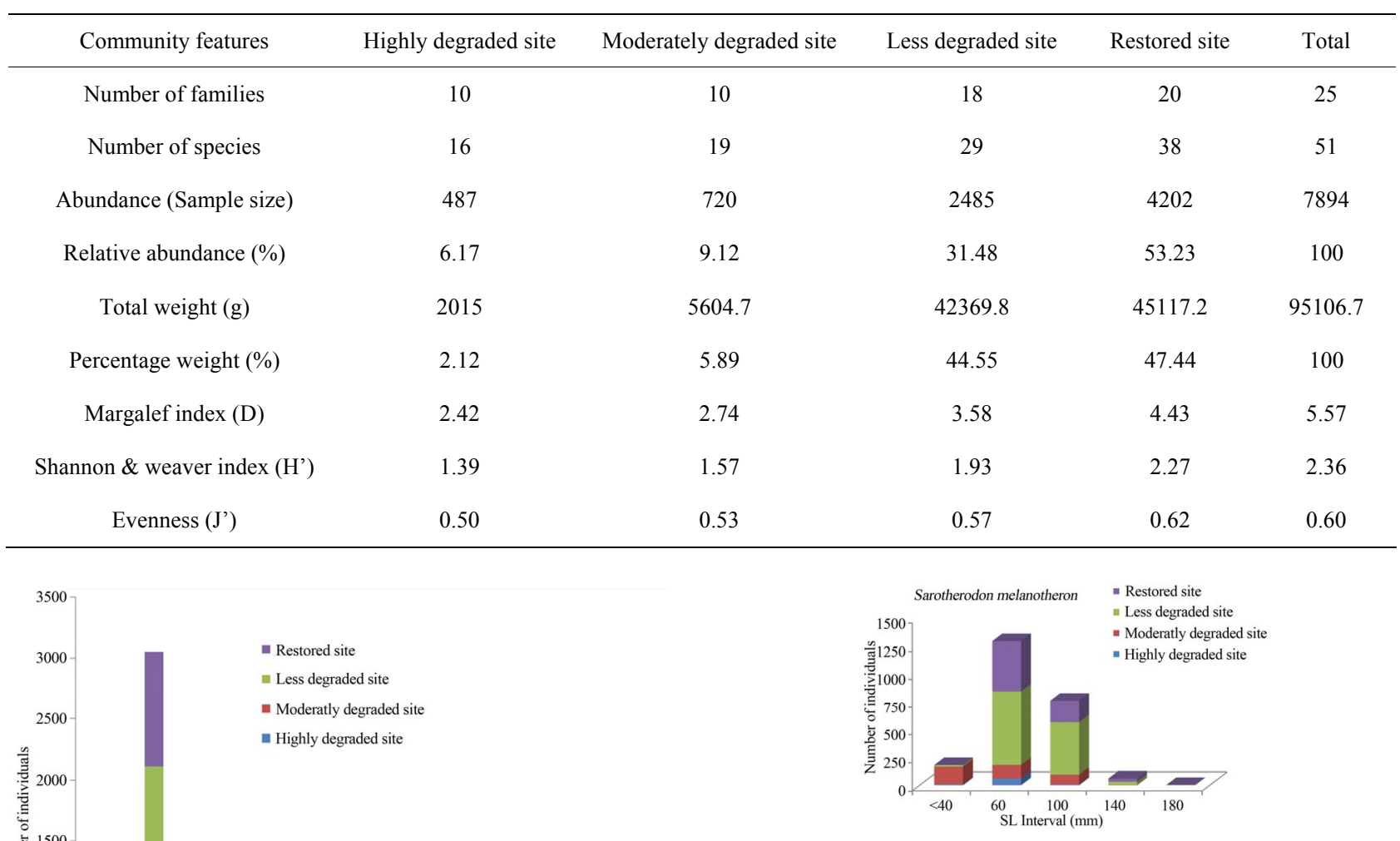

Figure 3. Size structure of Sarotherodon melanotheron $(\mathbf{n}=$ 2288) in the Benin mangrove zone.

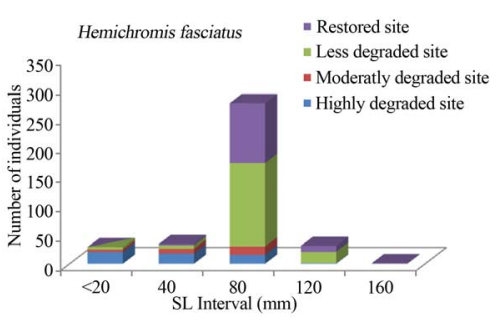

Figure 2. Fish abundance by family according to mangrove status in the Benin coastal zone. Families comprised a total of 33 genera and 51 species.

in the Benin mangrove zone. 
Fish Assemblages in the Degraded Mangrove Ecosystems of the Coastal Zone, Benin,

West Africa: Implications for Ecosystem Restoration and Resources Conservation

Table 5. Trophic categories, relative abundance and commercial importance of the fish caught in the mangrove ecosystem of the Benin coastal zone. J: juvenile; A: adult; HC: highly commercial; MC: moderately commercial; NV: no value.

\begin{tabular}{|c|c|c|c|c|}
\hline Trophic category \& Species & Relative abundance (\%) & Total weight (\%) & Life history stage & Fisheries importance \\
\hline Detritivores & 54.57 & 68.21 & & \\
\hline Chrysichthys nigrodigitatus & 1.35 & 4.66 & $\mathrm{~J} / \mathrm{A}$ & $\mathrm{HC}$ \\
\hline Dormitator lebretonis & 15.19 & 4.89 & $\mathrm{~J} / \mathrm{A}$ & $\mathrm{HC}$ \\
\hline Dormitator pleurops & 0.01 & 0.0008 & $\mathrm{~J}$ & MD \\
\hline Kriba nana & 0.49 & 0.06 & $\mathrm{~J} / \mathrm{A}$ & $\mathrm{HC}$ \\
\hline Ethmalosa fimbriata & 4.84 & 4.03 & $\mathrm{~J} / \mathrm{A}$ & $\mathrm{HC}$ \\
\hline Liza falcipinnis & 2.27 & 5.23 & $\mathrm{~J} / \mathrm{A}$ & $\mathrm{HC}$ \\
\hline Liza sp. & 0.29 & 0.007 & $\mathrm{~J}$ & $\mathrm{HC}$ \\
\hline Mugil curema & 0.79 & 1.60 & $\mathrm{~J} / \mathrm{A}$ & $\mathrm{HC}$ \\
\hline Mugil bananensis & 0.02 & 0.27 & $\mathrm{~J}$ & $\mathrm{HC}$ \\
\hline Mugil cephalus & 0.01 & 0.1 & $\mathrm{~J}$ & $\mathrm{HC}$ \\
\hline Mugil sp. & 0.32 & 0.64 & $\mathrm{~J} / \mathrm{A}$ & $\mathrm{HC}$ \\
\hline Sarotherodon melanotheron & 28.98 & 46.66 & $\mathrm{~J} / \mathrm{A}$ & $\mathrm{HC}$ \\
\hline Synodontis sp. & 0.01 & 0.01 & A & $\mathrm{MC}$ \\
\hline Planktinovores/microcarnivores & 30.41 & 9.81 & & \\
\hline Aplocheilichthys spilauchen & 13.71 & 1.22 & $\mathrm{~J} / \mathrm{A}$ & NV \\
\hline Epiplatys sp. & 0.02 & 0.0002 & $\mathrm{~J}$ & ND \\
\hline Gerres melanopterus & 12.90 & 6.22 & $\mathrm{~J} / \mathrm{A}$ & $\mathrm{HC}$ \\
\hline Gerres nigri & 0.03 & 0.03 & A & $\mathrm{HC}$ \\
\hline Oxyurichthys occidentalis & 1.10 & 1.22 & $\mathrm{~J} / \mathrm{A}$ & $\mathrm{HC}$ \\
\hline Pellonula sp. & 2.65 & 1.12 & $\mathrm{~J} / \mathrm{A}$ & $\mathrm{MC}$ \\
\hline Herbivores & 3.66 & 5.91 & & \\
\hline Tilapia guineensis & 2.28 & 2.29 & $\mathrm{~J} / \mathrm{A}$ & $\mathrm{HC}$ \\
\hline Tilapia zillii & 1.38 & 3.62 & $\mathrm{~J} / \mathrm{A}$ & $\mathrm{HC}$ \\
\hline Intermediate carnivores & 4.71 & 5.60 & & \\
\hline Caranx hippos & 1.11 & 0.71 & $\mathrm{~J} / \mathrm{A}$ & $\mathrm{HC}$ \\
\hline Citharichthys stampflii & 1.09 & 0.98 & $\mathrm{~J} / \mathrm{A}$ & MD \\
\hline Clarias gariepinus & 0.06 & 1.17 & A & $\mathrm{HC}$ \\
\hline Cynoglossus senegalensis & 0.03 & 0.19 & A & $\mathrm{MC}$ \\
\hline Dalophis sp. & 0.01 & 0.03 & A & $\mathrm{MC}$ \\
\hline Elops lacerta & 0.46 & 1.66 & A & $\mathrm{HC}$ \\
\hline Elops senegalensis & 0.06 & 0.20 & A & $\mathrm{HC}$ \\
\hline Hemichromis bimaculatus & 1.29 & 0.27 & $\mathrm{~J} / \mathrm{A}$ & $\mathrm{MC}$ \\
\hline Microphis brachyurus Aculeatus & 0.06 & 0.005 & A & NV \\
\hline
\end{tabular}




\begin{tabular}{|c|c|c|c|c|}
\hline Myrophis plumbeus & 0.01 & 0.05 & A & $\mathrm{MC}$ \\
\hline Pomadasys jubelini & 0.05 & 0.2 & $\mathrm{~J} / \mathrm{A}$ & $\mathrm{HC}$ \\
\hline Pomadasys peroteti & 0.01 & 0.01 & $\mathrm{~J} / \mathrm{A}$ & $\mathrm{HC}$ \\
\hline Pomadsys sp. & 0.14 & 0.12 & $\mathrm{~A}$ & $\mathrm{HC}$ \\
\hline Protopterus annectens & 0.01 & 0.17 & A & MC \\
\hline Progobius schlegeli & 0.32 & 0.24 & $\mathrm{~J} / \mathrm{A}$ & $\mathrm{HC}$ \\
\hline Top carnivores & 6.65 & 10.47 & & \\
\hline Cybium sp. 1 & 0.18 & 0.22 & $\mathrm{~J} / \mathrm{A}$ & $\mathrm{HC}$ \\
\hline Cybium sp. 2 & 0.15 & 0.25 & $\mathrm{~J} / \mathrm{A}$ & $\mathrm{MC}$ \\
\hline Eleotris daganensis & 0.03 & 0.05 & A & $\mathrm{MC}$ \\
\hline Eleotris senegalensis & 0.08 & 0.04 & $\mathrm{~J} / \mathrm{A}$ & $\mathrm{MC}$ \\
\hline Eleotris sp. & 0.98 & 1.96 & $\mathrm{~J} / \mathrm{A}$ & $\mathrm{MC}$ \\
\hline Eleotris vitatta & 0.09 & 0.22 & $\mathrm{~J} / \mathrm{A}$ & $\mathrm{MC}$ \\
\hline Epinephelus aeneus & 0.03 & 0.43 & $\mathrm{~J} / \mathrm{A}$ & $\mathrm{MC}$ \\
\hline Hemichromis fasciatus & 4.65 & 6.50 & $\mathrm{~J} / \mathrm{A}$ & $\mathrm{HC}$ \\
\hline Galeoides decadactylus & 0.02 & 0.01 & $\mathrm{~J}$ & $\mathrm{MC}$ \\
\hline Lutjanus agennes & 0.05 & 0.03 & $\mathrm{~J} / \mathrm{A}$ & $\mathrm{HC}$ \\
\hline Lutjanus goriensis & 0.14 & 0.17 & $\mathrm{~J} / \mathrm{A}$ & $\mathrm{HC}$ \\
\hline Lutjanus sp. & 0.05 & 0.09 & $\mathrm{~J} / \mathrm{A}$ & $\mathrm{HC}$ \\
\hline Parachana obscura & 0.01 & 0.23 & A & $\mathrm{MC}$ \\
\hline Psettia sebae & 0.11 & 0.09 & $\mathrm{~J} / \mathrm{A}$ & $\mathrm{MC}$ \\
\hline Strongylura senegalensis & 0.08 & 0.18 & $\mathrm{~A}$ & $\mathrm{MC}$ \\
\hline TOTAL OF INDIVIDUALS & 7894 & & & \\
\hline
\end{tabular}

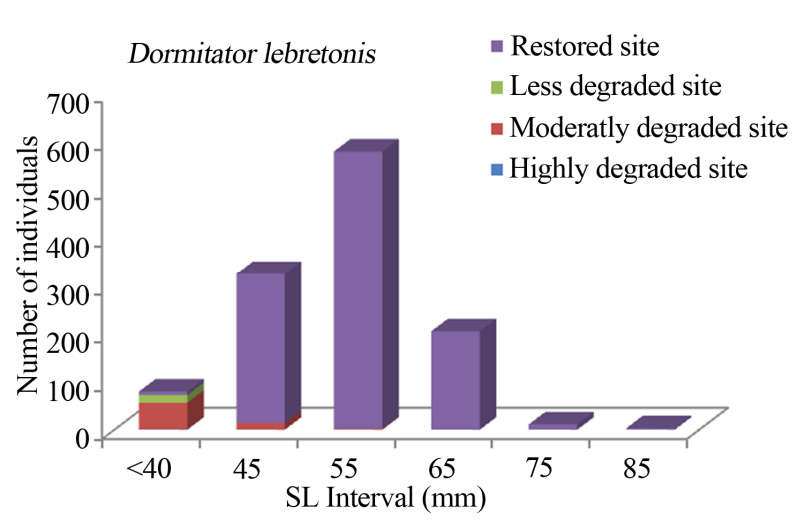

Figure 5. Size structure of Dormitator lebretonis $(\mathbf{n}=1199)$ in the Benin mangrove zone.

S. melanotheron was positively correlated with $\mathrm{ph}\left(\mathrm{r}^{2}=\right.$ 0.24 ) whereas the eleotrid D. lebretonis, abundant during the transitional season was negatively correlated with $\mathrm{pH}$ $\left(\mathrm{r}^{2}=0.36\right)$ and dissolved oxygen $\left(\mathrm{r}^{2}=0.10\right) . H$. fasciatus

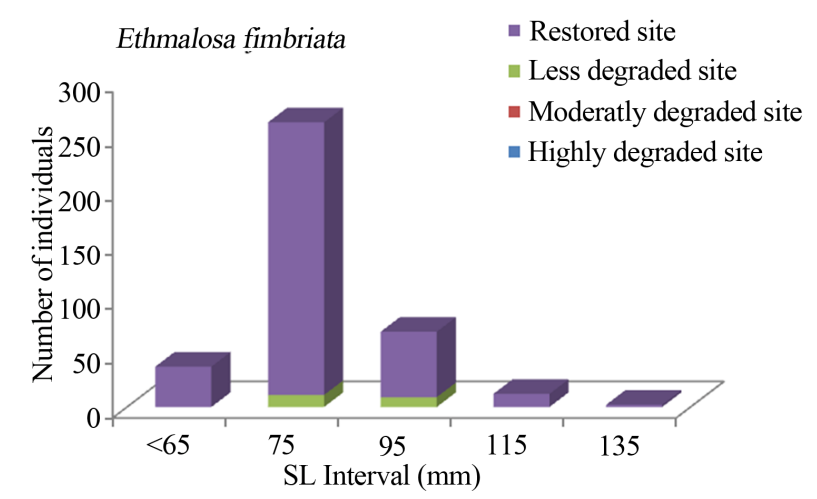

Figure 6. Size structure of Ethmalosa fimbriata $(n=382)$ in the Benin mangrove zone.

was negatively correlated with temperature $\left(\mathrm{r}^{2}=0.32\right)$. The Gerreid, G. melanopterus was positively correlated with dissolved oxygen $\left(r^{2}=0.14\right)$, transparency $\left(r^{2}=0.15\right)$ and depth $\left(\mathrm{r}^{2}=0.22\right)$. The clupeid E. fimbriata was posi- 


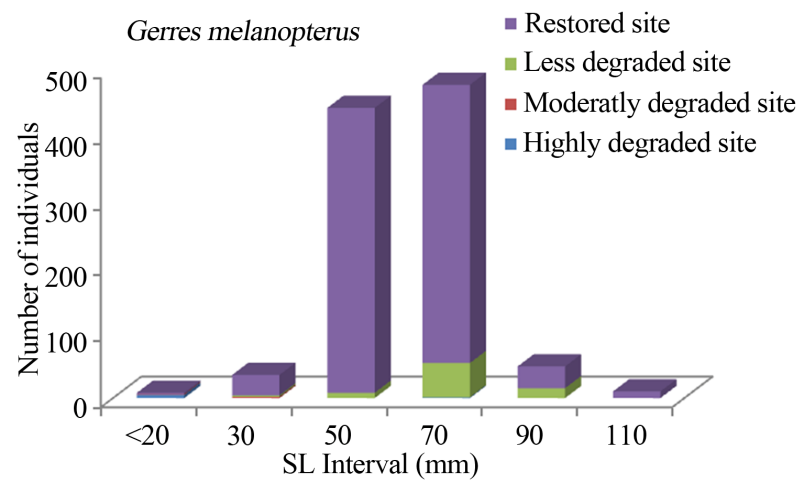

Figure 7. Size structure of Gerres melanopterus $(n=1018)$ in the Benin mangrove zone.

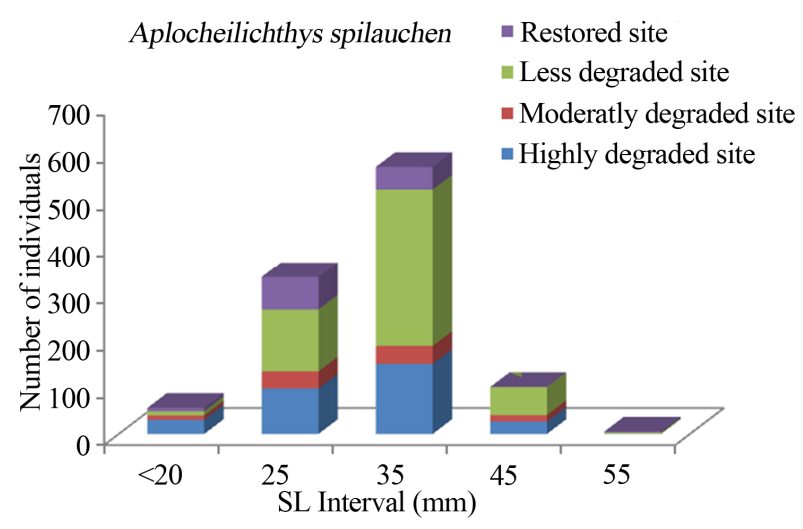

Figure 8. Size structure of Aplocheilichthys spilauchen $(\mathbf{n}=$ 1082) in the Benin mangrove zone.

tively correlated with dissolved oxygen $\left(r^{2}=0.16\right)$ and salinity $\left(r^{2}=0.12\right)$.

\subsection{Length-Weight Relationships and Fish Condition}

Total length-body weight regression equations were established to examine the conditions of the dominant fish species from different sites (Table 6). Overall, slopes ranged between 2.23 for A. spilauchen at a highly degraded site and 3.99 for E. fimbriata at a less degraded site with a significant $(\mathrm{p}<0.05)$ " $\mathrm{r}$ " ranging between 0.84 and 0.99 indicating that the dominant species exhibited an allometric growth in the mangrove ecosystem. In general, the "highly degraded" and the "moderately degraded" sites exhibited lower slopes whereas the "less degraded" and the "restored sites" had higher slopes.

\subsection{Commercial Values of Fishes}

Relative to economic value of the fishes, I classified fishes in three categories according to their commercial value: 1) fishes of high commercial value $(\mathrm{HC}), 2)$ fishes of moderate commercial value (MC), and 3)
Table 6. Linear regressions (Log SL-Log W) by habitat type of the dominant fish species of the Benin mangrove ecosystem.

\begin{tabular}{cccccc}
\hline Species-Habitats & $\begin{array}{c}\text { Number of } \\
\text { individuals }\end{array}$ & $\begin{array}{c}\text { Slope } \\
\text { (b) }\end{array}$ & $\begin{array}{c}\text { Intercept } \\
\text { (a) }\end{array}$ & $\mathbf{r}^{2}$ & $\mathbf{r}$ \\
\hline $\begin{array}{c}\text { Sarotherodon } \\
\text { melanotheron }\end{array}$ & & & & & \\
Higly degraded & 80 & 2.809 & -3.398 & 0.92 & 0.96 \\
Moderatly degraded & 361 & 2.758 & -4.301 & 0.98 & 0.99 \\
Less degraded & 1175 & 2.779 & -4.222 & 0.94 & 0.97 \\
$\quad$ Restored & 672 & 2.864 & -3.398 & 0.93 & 0.96
\end{tabular}

Dormitator lebretonis

$\begin{array}{cccccc}\text { Higly degraded }^{*} & 1 & - & - & - & - \\ \text { Moderatly degraded } & 71 & 2.941 & -5 & 0.78 & 0.88 \\ \text { Less degraded } & 18 & 2.989 & -4 & 0.88 & 0.94 \\ \quad \begin{array}{c}\text { Restored } \\ \begin{array}{c}\text { Aplocheilichthys } \\ \text { spilauchen }\end{array}\end{array} & 1109 & 2.978 & -4 & 0.85 & 0.94 \\ \begin{array}{c}\text { Higly degraded } \\ \begin{array}{c}\text { Moderatly degraded } \\ \text { Less degraded }\end{array}\end{array} & 290 & 2.388 & -4.52 & 0.81 & 0.90 \\ \quad 565 & 2.790 & -4.52 & 0.71 & 0.85 \\ \quad \text { Restored } & 130 & 2.777 & -4 & 0.75 & 0.87\end{array}$

Gerres melanopterus

$\begin{array}{cccccc}\text { Higly degraded } & 3 & 2.315 & -3 & 0.70 & 0.84 \\ \text { Moderatly degraded } & 8 & 2.939 & -4.70 & 0.99 & 0.99 \\ \text { Less degraded } & 84 & 2.943 & -5 & 0.95 & 0.97 \\ \text { Restored } & 923 & 3.152 & -4.22 & 0.89 & 0.94\end{array}$

Ethmalosa fimbriata

Higly degraded

Moderatly degraded*

Less degraded

Restored

$\begin{array}{lllll}20 & 3.987 & -7 & 0.91 & 0.95\end{array}$

$\begin{array}{lllll}362 & 2.866 & -4.70 & 0.78 & 0.88\end{array}$

Hemichromis fasciatus

$\begin{array}{cccccc}\text { Higly degraded } & 53 & 2.712 & -4.22 & 0.99 & 0.99 \\ \text { Moderatly degraded } & 26 & 3.049 & -5 & 0.96 & 0.98 \\ \text { Less degraded } & 173 & 2.882 & -4.52 & 0.96 & 0.98 \\ \quad \text { Restored } & 115 & 3.117 & -5 & 0.94 & 0.97\end{array}$

${ }^{*}$ Linear regression equations have not been determined because there were no individuals or insufficient number of individuals for the species in the habitat category, and associated "-" means no value. 
fishes with no commercial value (NC) and not utilized as food and were not sold in the fish market. From the fish sampled, about $74 \%$ had a high economic value, from which $74 \%$ were juveniles and adults (Table 5). Only three species (A. spilauchen, Epyplatys sp., Mycrophis brachyurus aculeatus) of small sizes had no commercial value.

\subsection{Mangrove Resource Utilization and Degradation Sources}

Classic ecological role of mangrove are to provide nursery ground, food, shelter etc. However, survey in grassroots village at the coastal zone, revealed that mangroves are destroyed in many villages for firewood, building houses and to make space for local salt industries. In fisheries, mangrove was massively destroyed to build "Akadja", a fisheries park of branches installed in the lagoon and utilized to attract fishes [9]. Though at small scale, some fish ponds have been built in the mangrove habitats for aquaculture. Also, adjacent wetlands colonized by Paspalum vaginatum, were intensively utilized to grow legumes, onions, carrots, red papers, tomatoes, etc. causing pesticides and fertilizers intrusion and habitat pollution. Organic pollution occurs nearby the fishermen village through a daily dumping of huge domestic wastes. The overexploitation of fish resources was caused by the increasing fishermen population and the use of various fishing gears. For example, the use of the cross-lake fish traps, less selective was very detrimental for species survival. Another major source of degradation was the hydro electrical dam constructed on the Mono River to provide the two countries, Togo and Benin, with electricity.

\section{Discussions}

\subsection{Physical Conditions}

Though the combined effects of the physical parameters determine aquatic habitat quality, the seasonal variability of the salinity $(0 \%$ - $35 \%$ ) appears to be one of the major factor affecting the coastal lagoon conditions and ichtyofaunal structure and distribution [8]. This variability depends on factors such as seasons (wet, transitional, dry), distances of the sites from the Mouth River, flood intensity and tides [7]. Indeed, salinities from sites close to the tidal pass were always high and oceanic (Djondji village: $31 \%-33 \%$ ). On the contrary, the water quality was predominantly freshwater (Grand-Popo village: $0 \%$ 6\%) at sites close to the Mono River mouth. Laegdsgaard \& Johnson [8], Williamson et al. [30], Yanez-Arancibia et al. [31] and Vance et al. [3] have reported the same trends for the subtropical mangroves in eastern Australia, inshore habitats of Raby Bay, Queensland,
Terminos Lagoon in Mexico, and for the mangrove forest in northern Australia, respectively. Though recorded water features were globally favorable for the growth and survival of the fish resources, however, the low depths and transparencies, the acid $\mathrm{pH}$, and the relatively high temperatures (Table 2) recorded at the "highly degraded site" and at "moderately degraded site" were critical for optimal growth of the fish resources.

\subsection{Fish Community Structures}

The present study consistently showed that the computed community structure indices were lower for the "highly degraded site" and "moderately degraded site" and higher indices were recorded in "less degraded site" and "restored site" (Tables 3 and 4). This result evidenced the negative impact of the mangrove destruction on the fish community structure and, probably on the whole biodiversity. Moreover, the fish composition of the mangrove ecosystem of Benin is greatly dominated by marine-estuary species whereas the number of typically rivers fish species was reduced. Indeed, on a total of 51 fish species inventoried, only 11 species $(20 \%)$ originated from the Mono River and the remaining $(80 \%)$ originated from the marine/estuarine environment. This situation was probably due to the recent evolution of the coastal lagoon water quality, caused by the construction of a hydro electrical dam on the Mono River which has profoundly modified the hydrological system and flooding regime, with a probable modification of the fish community structure [12]. Nevertheless the results obtained follow the general pattern of the mangrove habitats characterized by relatively high species richness. For example, 87 species were inventoried in the bay of Martinique Island [32], 80 in Terminos Lagoon of the Gulf of Mexico [31], 53 in the Moreton Bay in eastern Australia [8], and 44 in the Raby Bay [29], including common families (Mugilidae, Clupeidae, Gerreidae, Carangidae, Gobiidae, Ludjanidae, Eleotridae, Elopidae, Belonidae, Serranidae Pomadasidae, Monodactylidae etc.) recorded in the Benin coastal fish community $[7,25,27]$.

With regard to species, the cichlid, S. melanotheron dominated the Benin mangrove fish assemblage with a numeric relative abundance of $29 \%$. This trend is typical for the Benin brackish waters (Lake Nokoue, Lagoon of Porto-Novo, and Lake Aheme) where S. melanotheron occurred abundantly and is always the first dominant species [5,16,33]. The relatively high abundance of $H$. fasciatus at the mangrove fringe compared to the other habitats may indicate a relatively high predation in or around the mangrove forest. The freshwater-preferred species such as Pellonula sp. mostly occurred at the Mono River mouth where salinities were always low. Particularly, the eleotrid D. lebretonis (15.19\%) occurred 
mostly in open water during flooding. Indeed, during wet season, this species reproduces and inhabits mangrove root systems and muddy vegetated habitats, and when the flooding occurs, they are flushed abundantly in the open water. A. spilauchen $(13.71 \%)$, of small size, dominated the mangrove fringe to avoid high water current and predation, and G. melanopterus $(12.90 \%)$ dominated the Adjacent open water. Like the other aquatic ecosystem, intensive multi-species fishery occurred at the Benin coastal lagoon where about $94 \%$ of the fish species was exploited.

The trophic guilds depicted in the fish community of the Benin coastal zone, partially reflected the fragmentized habitats of the degraded mangrove ecosystems which were consistently and numerically dominated by the detritivores $(54.57 \%)$ and the planktinovores/microcarnivores $(30.41 \%)$ fish species. Laegdsgaard \& Johnson and Halliday \& Young $[8,25]$ reported similar trends of trophic structures in mangrove-lined estuaries where detritivores and planktinovores/microcarnivores were numerically among the major trophic categories in Moreton Bay and in the Tin Can Bay of Australia. Probably, there has been an evolutionary process of the mangrove fish communities in association with the major available food, namely detritus and planktons $[26,34,35]$. That is, fishes have evolved to better exploit the large mass of mangrove leaves which falls and decays in permanence in the coastal zone system generating a huge amount of substrate and planktons [36-38]. Such substrate harbors plenty of biotic and abiotic foods. In contrast, the abundance of top-carnivores tended to be reduced $(6.65 \%)$ even though the number of species was relatively high, indicating a degree of predation in the mangrove zone (Table 5).

The study consistently revealed that the fish assemblages of the Benin mangrove ecosystem were dominated by juvenile individuals. As reported by Laegdsgaard \& Johnson [8], mangrove habitats are unique in their function as nurseries and many fish species enter estuaries as post larvae and juveniles. In the Alligator Creek in Australia, Roberston \& Duke [7] reported a high abundance of post-larvae, juveniles and small adults in the mangrove area. In addition to the role of nursery, small sizes fish prefer calm and shallow environment to avoid high current and predation. Nevertheless, the overfishing, combined with the destruction of the mangrove, could act to modify the fish community structure of the mangrove habitats with dominance of small sizes. In general, the dominant species exhibited variation in size according to habitats. Indeed, one-way ANOVA on the standard length (SL) of the dominant fish species from different study sites, indicated that the SL, across the four habitats ("highly degraded", "moderately degraded", "less de- graded", "restored"), were significantly different ( $p \leq$ $0.0001)$. The calculted $F$-values, along with degrees of freedom and $p$-values were $F_{3,2287}=120.298, p=0.0001$ for $S$. melanotheron, $F_{3,366}=57.224, p=0.0001$ for $H$. fasciatus, $F_{3,1198}=324,361, p=0.0001$ for D. lebretonis, $F_{3,1017}=48.984, p=0.0001$ for G. melanopterus, and $F_{1,1081}=14.847, p=0.0001$ for A. spilauchen. Overall, for the six dominant species, higher sizes were found in the less degraded and restored habitats (Figures 2-7). However, no significant difference $\left(F_{1,381}=3.164, p=\right.$ 0.08 ) was found in the size of $E$. fimbriata occurring only in the less degraded and restored sites (Figure 5).

\subsection{Degradation Impacts}

The multiple utilization of the mangrove may be quailfied as an ecological disaster causing, a reduction and loss of nursery grounds and shelters, a modification of habitats conditions and changes in mangrove faunal composition [34]. Like trends reported for lagoon Toho in southern Benin [5], at some locations, the mangrove cutting has favored, low water depth, sediment loading, shallow and muddy bottom. Consequently, these changing habitat conditions, coupled with the high temperatures, high turbidities and oxygen depletion have lead to a progressive colonization of some sites by a grass, $P$. vaginatum, precursor of terrestrial formation, thus reducing the coastal lagoon area with the loss of habitats and inhabiting biodiversity.

Also, the hydro electrical dam had greatly modified the Mono River flooding regime with a reduction of the water volume released in the coastal lagoon system. This situation has led to a reduction of inundated plains with changes in water quality, mainly salinity [12]. Consequently, the species composition is being modified: on a total of 51 species collected from the coastal zone, only 11 species $(20 \%)$ originated from the Mono River and the remaining $(80 \%)$, originated from the marine-estuarine environment. As a result, fish composition tends to be greatly dominated by marine-estuary fishes whereas the number of rivers fish species was reduced. Also, the reduction of inundated plain may affect the nursery grounds and shelters, with a change in fish reproduction success, recruitment and a probable decrease of the fish abundance. During our collection, most fishermen complain about the impact of the hydro electrical dam on the fish production. According to them, some species such as D. lebretonis (Eleotridae), which reproduce and grow in the mangrove and vegetation, required the flooding in their life cycle to be abundant and catchable in the open water. The absence of some freshwater species such as Heterotis niloticus (Osteoglossidae) in the present collection may be attributed to the change in coastal water salinity [10]. As a result, the recent evolution of the hy- 
drology of the Mono River, combined with mangrove degradation has profoundly modified the ecological status of the Benin coastal zone, including changes in fish community structure.

\subsection{Management Implications and Conclusions}

This investigation provide valuable information on mangrove fishes of the Benin coastal zone especially habitat conditions, species composition, distributional pattern of the fishes, disturbance and removing of major habitat for fishes, and overall degradation issues. Also, the research has revealed the great importance of the coastal zone when considering its multiple utilization and the fish resources inhabiting this ecosystem. In addition to the mangrove degradation, the most distinctive feature of the Benin mangrove-lined estuary was the modification of the Mono flooding regime which greatly affects the hydrology of the coastal zone and the living aquatic resources.

To date, little is known about the diversity and richness of the Mono River and the impacts of the hydro electrical dam built on this river [12]. Thus, there is a great need of biological and ecological research on the Mono River and ecosystem response from the construction of hydro electrical dam. Nevertheless, based on the present investigation, an integrated approach of mangrove resource management is required for ecosystem restoration. This program should include 1) pursuing mangrove restoration (planting) program in a participatory approach with grassroots mainly fishermen, 2) seagrass (Cyperus articulatus) plantation to increase the nursery grounds, 3) plantation of trees for firewood to lessen mangrove cutting for fuel and other domestic utilization, 4) making the mangrove zone as protected area or a reference selected site as a sanctuary /classified zone, 5) developing ecological sound ecotourism involving grassroots to reduce pressure on mangrove ecosystem resources, 6) strengthening and re-enforcing regulation about fishery activities, 7) supporting the fisheries and aquaculture of the mangrove oyster, Crassostrea $s p$., the freshwater prawn, Macrobrachium sp., peneids shrimps, crabs (Callinectes sp., Cardiosoma sp.), inhabiting the mangrove zone to increase grassroots revenue and to reduce fishing pressure, 8) developing an integrated environmental education program and 9) developing an environment monitoring program to periodically assess the health of the mangrove ecosystem.

\section{Acknowledgements}

Research funding was provided by the International Foundation for Science (IFS). We express our gratitude to the anonymous reviewers for reviewing the earlier version of the manuscript. We especially thank Mrs. Ingella Taxell from IFS for her permanent assistance and Rene Djessou for helping during the survey.

\section{REFERENCES}

[1] F. K. E. Nunoo, E. Sossoukpe, A. Adite and E. D. Fiogbe, "Foods Habits of Two Species of Pseudotolithus (Scianidae) off (West Africa) near Shore Waters and Implications for Management," International Journal of Fisheries and Aquaculture, Vol. 5, No. 6, 2013, pp. 142-151.

[2] R. L. Welcomme, "Fisheries Ecology of Floodplain Rivers," Longman, New York, 1979.

[3] D. J. Vance, M. D. Haywood, D. S. Heales, R. A. Kenyon and N. R. Loneragan, "How Far Prawns and Fish Move into Mangroves? Distribution of Juvenile Banana Prawns, Penaeus merguiensis and Fish in a Tropical Mangrove Forest in Northern Australia," Marine Ecological Progress Series, Vol. 131, 1996, pp. 115-124.

[4] G. W. Thayer, D. R. Colby and W. F. Hettler Jr., "Utilization of the Red Mangrove Prop Root Habitat by Fishes in South Florida," Marine Ecological Progress Series, Vol. 35, 1987, pp. 25-38.

http://dx.doi.org/10.3354/meps035025

[5] A. Adite, "Fishery Ecological Survey of Natural Coastal Lakes of Benin, West Africa," Master of Sciences Thesis, Texas A\&M University, College Station, 1995.

[6] A. Roberston and N. C. Duke, "Mangrove as a Nursery Sites: Comparisons of the Abundance and Species Composition of Fish and Crustaceans in Mangroves and Other near Shore Habitats in Tropical Australia," Marine Biology, Vol. 96, No. 2, 1987, pp. 193-206. http://dx.doi.org/10.1007/BF00427019

[7] W. N. Tzeng and Y. T. Wang, "Structure, Composition and Seasonal Dynamics of the Larval and Juvenile Fish Community in the Mangrove Estuary of Tanshui River, Taiwan," Marine Biology, Vol. 113, No. 3, 1992, pp. 481490. http://dx.doi.org/10.1007/BF00349175

[8] P. Laegdsgaard and C. R. Johnson, "Mangrove Habitats as Nurseries: Unique Assemblages of Juvenile Fish in Subtropical Mangroves in Eastern Australia," Marine Ecological Progress Series, Vol. 126, No. 1-3, 1995, pp. 67-81. http://dx.doi.org/10.3354/meps 126067

[9] R. L. Welcomme, "A Description of Certain Indigenous Fishing Methods from Southern Dahomey," African Journal of Tropical Hydrobiology and Fisheries, Vol. 1, No. 2, 1971, 129-140.

[10] A. Adite and R. Van Thielen, "Ecology and Fish Catches in Natural Lakes of Benin, West Africa," Environmental Biology of Fishes, Vol. 43, No. 4, 1995, pp. 381-391. http://dx.doi.org/10.1007/BF00001173

[11] P. Lalèyè, C. Niyonkuru, J. Moreau and G. G. Teugels, "Spatial and Seasonal Distribution of the Ichthyofauna of Lake Nokoué, Benin, West Africa," African Journal of Aquatic Science, Vol. 28, No. 2, 2003, pp. 151-161. http://dx.doi.org/10.2989/16085910309503779

[12] A. Adite, Y. Abou, E. Sossoukpe and E. D. Fiogbe, "The 
Oyster Farming in the Coastal Ecosystem of Southern Benin (West Africa): Environment, Growth and Contribution to Sustainable Coastal Fisheries Management," International Journal of Development Research, Vol. 3, No. 10, 2013, pp. 087-094.

[13] H. Lopez-Fernandez, K. O. Winemiller, A. Adite, D. A. Arrington and C. A. Layman, "Freshwater Fish Diversity in Benin, West Africa, and Challenge for Its Conservation," Proceedings University of Abomey-Calavi Conference African Fish and Fisheries, Abomey-Calavi, 2003, pp. 85-86.

[14] C. Levêque, D. Paugy and G. G. Teugels, "The Fresh and Brackish Water Fishes of West Africa," Tome 1, Editions ORSTOM/MRAC, Paris, 1990.

[15] C. Levêque, D. Paugy and G. G. Teugels, "The Fresh and Brackish Water Fishes of West Africa," Tome 2, Editions ORSTOM/MRAC, Paris, 1990.

[16] M. Holden and W. Reed, "West African Freshwater Fish,” Longman Group Ltd. London, 1972.

[17] R. H. Lowe McConnell, "Fish Communities in Tropical Freshwaters," Longman, London, 1975.

[18] R. H. Lowe McConnell, "Ecological Studies in Tropical Fish Communities," Cambridge University Press, Cambridge, 1987.

[19] R. Margalef, "Perspective in Ecological Theory," University of Chicago Press, Chicago, 1968.

[20] C. Shannon and E. Weaver, "The Mathematical Theory of Communication," University of Illinois Press, Urbana, 1963.

[21] C. J. Krebs, "Ecological Methodology," Harper \& Row Publishers, New York, 1989.

[22] B. McCune and M. J. Mefford, "Multivariate Analysis of Ecological Data. Version 2.0. MJM Software Design," Gleneden Beach, Oregon, 1995.

[23] S. J. M. Blader and T. G. Blader, "Factors Affecting the Distribution of Juvenile Estuarine and Inshore Fish," Journal of Fish Biology, Vol. 17, No. 2, 1980. pp. 143162.

http://dx.doi.org/10.1111/j.1095-8649.1980.tb02749.x

[24] R. M. Morton, "Community Structure, Density, and Standing Crop of Fishes in a Subtropical Australian Mangrove Area," Marine Biology, Vol. 105, No. 3, 1990, pp. 385394. http://dx.doi.org/10.1007/BF01316309

[25] I. A. Halliday and W. R. Young, "Density, Biomass and Species Composition of Fish in a Subtropical Rhizophora stylosa Mangrove Forest," Marine Freshwater Resources, Vol. 47, No. 4, 1996, pp. 609-615. http://dx.doi.org/10.1071/MF9960609

[26] A. Adite and K. O. Winemiller, "Trophic Ecology and Ecomorphology of Fish Assemblages in Coastal Lakes of
Benin," Ecoscience, Vol. 4, No. 1, 1997, pp. 6-23.

[27] A. Adité, K. O. Winemiller and E. D. Fiogbe, "Ontogenetic, Seasonal; and Spatial Variation in the Diet of Heterotis niloticus (Osteoglossiformes: Osteoglossidae) in the Sô River and Lake Hlan, Benin, West Africa," Environmental Biology of Fishes, Vol. 73, No. 4, 2005, pp. 367-378. http://dx.doi.org/10.1007/s10641-004-5563-9

[28] G. A. Morgan, O. V. Grieggo and G. W. Gloekner, "SPSS for Windows: An Introduction to Use and Interpretation in Research," Lawrence Erlbaum Associates, Publishers, Mahwah, 2001.

[29] F. W. Tesh, "Age and Growth," In: W. E. Ricker, Ed., Methods for Assessment of Fish Production in Fresh Waters, Blackwell Scientific Publication, London, 1971.

[30] I. Williamson and C. B. King Mather, "A Comparison of Fish Communities in Unmodified and Modified Inshore Habitats of Raby Bay, Queensland," Estuarine, Coastal and Shelf Sciences, Vol. 39, No. 4, 1994, pp. 401-411. http://dx.doi.org/10.1006/ecss.1994.1072

[31] A. Yanez-Arancibia, A. Lara-Dominguez and J. W. Day Jr., "Interactions between Mangrove and Sea Grass Habitats Mediated by Estuarine Nekton Assemblages: Coupling of Primary and Secondary Production," Hydrobiologia, Vol. 264, No. 1, 1993, pp. 1-12. http://dx.doi.org/10.1007/BF00014659

[32] M. Louis, C. Bouchon and Y. Bouchon-Navaro, "Spatial and Temporal Variations of Mangrove Fish Assemblages in Martinique (French West Indies)," Hydrobiologia, Vol. 295, No. 1-3, 1995, pp. 275-284. http://dx.doi.org/10.1007/BF00029134

[33] GCLME, "Guinea Current Large Marine Ecosystem Report,” GEF/UNIDO/UNDP/UNEP/US-NOAA, 2006. http://Projects.csg.uwaterloo.ca/inweh/content/1188

[34] S. H. Bowen and B. R. Allanson, "Behavioral and Trophic Plasticity of Juvenile Tilapia mossambica in Utilization of the Unstable Littoral Habitat," Environmental Biology of Fishes, Vol. 7, No. 4, 1982, pp. 357-362.

[35] K. O. Winemiller, "Spatial and Temporal Variation in Tropical Fish Trophic Network," Ecological Monographs, Vol. 60, No. 3, 1990, pp. 331-367.

[36] S. H. Bowen, "Detrivory in Neotropical Fish Communities," Environmental Biology of Fishes, Vol. 9, No. 2, 1983, pp. 137-144.

[37] K. O. Winemiller, "Ecomorphological Diversification in Lowland Freshwater Fishes," National Geographic Research \& Exploration, Vol. 8, No. 3, 1992a, pp. 308-327.

[38] K. O. Winemiller, "Fish Assemblages across a Complex, Tropical Freshwater/Marine Ecotone," Environmental Biology of Fishes, Vol. 34, No. 1, 1992, pp. 29-50. 